\title{
POVERTY RISK TREND IN SLOVAKIA: CHANGES IN TIME AND SPACE
}

\author{
Anton MicháLEK \\ Institute of Geography, Slovak Academy of Sciences, Bratislava, Slovakia
}

Manuscript received: June 29, 2017

Revised version: October 17, 2017

\begin{abstract}
Michálek A., 2017. Poverty risk trend in Slovakia: Changes in time and space. Quaestiones Geographicae 36(4), Bogucki Wydawnictwo Naukowe, Poznań, pp. 93-102, 4 figs.

AвSTRACT: Poverty is a serious problem in Slovakia, and it is concentrated in a few regions. The aim of this paper is to capture the spatial differences in poverty in order to identify the poorest districts and to point to the change in the development of poverty in regions during one decade (2001-2011). It was an important period, because it was when Slovakia joined the EU (2004) and the euro zone (2009), that the financial crisis appeared. Our approach to the topic of poverty is based on an aggregated poverty indicator. The indicator reflects three kinds of risks and a broad spectrum of poverty aspects.

KEY WORDS: poverty risk, aggregated indicator, districts, Slovakia

Corresponding author: Anton Michálek, Institute of Geography, Slovak Academy of Sciences, Štefánikova 49, 81438 Bratislava, Slovakia.
\end{abstract}

\section{Introduction}

Dynamic development in Slovakia has, apart from other things, significantly spurred an increase in disparities within the society and between regions. Growing social and regional differences lead to larger spatial concentration of poverty in Slovakia. The aim of this paper is to capture tendencies in regional disparities from the point of view of poverty risk in Slovakia in the period from 2001 to 2011. It has been an important period, because it was when Slovakia joined the EU (2004) and the euro zone (2009). This paper studies changes in spatial differences in poverty and identifies the number of poor regions (districts) and the depth of their poverty. An aggregated indicator of poverty based on a broad interpretation and approach to poverty (poverty as a complex social phenomenon) was applied. Based on the obtained results, the author attemps to identify not only the poverty risk level but also its development, changes and trends in regions. Three basic characteristics of poverty risk are analysed by the method of descriptive comparison that makes it possible to capture the changes and trends in the development of poverty risk in the above-mentioned period.

\section{Theoretical and conceptual framework}

The view of poverty can be simplified to a great extent if estimated by income only. It does not provide accurate information about the spread and severity of poverty in regions. That is why it is appropriate to study poverty from various aspects. Such an approach makes it possible to better comprehend poverty (Michálek 
2004). Wagle (2008) talks about three dimensions of poverty: economic welfare, capacities and social inclusion. These three dimensions reflect different manifestations of poverty. Economic conditions determine physical resources, which in turn determine the material quality of life. The dimension of capacities creates the inner quality of life. Social inclusion represents means necessary for preservation of the social quality of life in association with the economic welfare and freedom. Social processes determine to some extent who is "in" and who is "out" in terms of economic, political, social, civic or cultural integration into society. Conventional approaches using income or consumption view poverty as an economic problem, which does not depend on the issues of capacities or relationships (Wagle 2008). Statistical Office of the European Union (EUROSTAT), following the same principle and using the multidimensional poverty model, has prepared an analysis for the identification of individuals threatened by poverty or social exclusion. The overall risk the poverty or exclusion may entail consists of: the rate of poverty risk, material deprivation and low work intensity ${ }^{1}$. People are considered poor or socially excluded if they are exposed to one of the above-mentioned risks. The nature and depth of poverty depends on the position in a multidimensional poverty mode. The determination of a poverty level starts with the identification of poverty in each of the three dimensions, which constitute the basis for multidimensional poverty. The poor are those who do not reach the minimum limit of one of the three dimensions (Fig. 1).

The very poor are those below the determined poverty limit in two dimensions, and the poorest are those that do not reach the minimum limit in any of the three dimensions. These three groups of the poor simultaneously represent the different poverty levels. The poorest are deprived of material and financial resources; they have low work intensity and the smallest chance to escape poverty. This group is characterised or afflicted

Work intensity of a household is the ratio between the number of months worked by all members of a household in the active age during the referred income period and the overall number of months that could have been theoretically worked. Low work intensity is the one below 20\% (Śtatistický úrad Slovenskej republiky 2012).

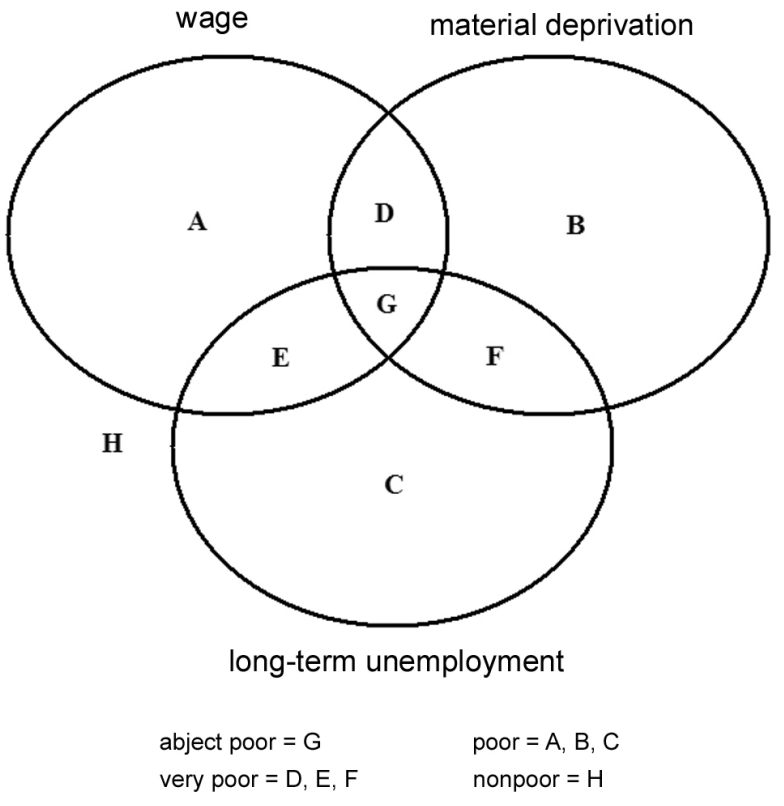

Fig. 1. Aggregated indicator of poverty and social exclusion.

Source: processed by Wagle (2008) and EU SILC (2011).

by what is referred to as chronic (permanent) or long-term poverty. The second group, which is poor only in two dimensions, is continuously threatened with the fall to the poorest group. The last group of poverty suffering only from one dimension stands the best chance of escaping it.

\section{Method of poverty risk analysis and its development in the regions of Slovakia}

Measuring poverty relates to and depends on the territorial aspects and (specific) conditions of the particular country. It means that there exist multiple different approaches and research and/or assessment methods (Townsend 1979; Nolan and Whelan 1996; Ravallion and Sell 1996; Lipton 1997; and others). In many countries (cases), generally approved methods and approaches to measurement of poverty are used, albeit they often have to be modified with respect to the specific conditions and needs of countries and regions. The modified aggregated indicator was used here and it was based on three kinds of risks: wages that express the rate of poverty risk, material deprivation and long-term unemployment (LTU), which replaced work intensity because of unavailable exact regional data. The aggregated indicator, adjusted and modified in this 
way, reflects the specific conditions of Slovakia associated, first of all, with the low wage level and the problems of high LTU. More important$1 y$, it captures and reflects at the same time the regional differences in poverty. The three kinds of risks were observed in the selected years 2001 and 2011. Poverty risk (low wages) is based on the value of the mean gross nominal monthly wages of an employee in districts of the SR. Deprived districts in terms of wages were $20 \%$ of the districts of the set with the value equal or lower than (lower quintile). Materially deprived districts were the ones that faced inner deprivation in terms of at least three of six deprivation items (central heating, the possession of a car, the ownership of a computer, a cell phone, access to the Internet, lacking a water main and a water source outside the dwelling). When choosing the deprivation items, the accessibility of relevant data was first considered. Districts were arranged in a descending order for each deprivation item, and lower or upper quintiles were computed. For each deprivation item, $20 \%$ of the districts with the equal or lower value of the lower quintile or $20 \%$ of the districts with the equal or higher value than the upper quintile were chosen, depending on the character of the deprivation item. Long-term unemployment (LTU) was computed as the proportion of the jobless who have been unemployed over 24 months to the overall number of the unemployed. Deprived districts in terms of LTU were $20 \%$ of the districts with the equal or higher value than the upper quintile. Data from the Regional Database of the Statistical Office (ŠÚ SR) and the Centre of Work, Social Affairs and Family (UPSVAR) were used in the analyses. The poorest regions are those deprived of three partial indicators. The second group of poor districts consists of those deprived of two partial indicators, and the third group contains districts deprived of one indicator. This procedure was applied to data for the years 2001 and 2011. The results were then compared, and changes that took place in the concerned decade were evaluated.

\section{Poverty risk in terms of wage}

Spatial disparities in wages and the associated concentration of the population earning low wages in certain areas or settlements cause the marginalisation of such areas and a difficult financial situation of the population group concerned. It is therefore important to observe and compare situations in regions. Wages in Slovakia are spatially diversified, and their amounts depend on multiple factors, such as the accessibility and qualifications of labour, education, a particular industry, the age category, a legal form of company, an owner (a foreigner, a native), an employment rate in the region and others. The development of wages is an important economic indicator with a profound impact on the competitiveness of companies at the micro level and on the macroeconomic stability of the national economy. Hrabcová (2000) discerns four most important functions of wages. First, it is the supporting function connected with the provision of the basic worker's needs. Wages and their amounts are among the fundamental determinants of differences within the society, of social classes, and it controls the social status of citizens. Wages are also the means to protect the minimum living standard by establishing their minimum value. The second function is a regulatory one; it exceeds the individual dimension and steps in the labour market. The wage rate determines the mobility of labour, an unemployment rate in certain sectors and leads to differences in jobs in terms of attractiveness. Low wages can lead to higher unemployment and a greater number of people depending on social benefits. Then, the government can temporarily reduce levies, which will be manifested in increased wages. The third (compensating function) is associated with physically and mentally demanding jobs when the wage to a certain extent must compensate for the negative impact of work on a human organism. The last function is the motivating and stimulating one. It is an effect on the behaviour of an employee controlled by a satisfaction with the received and required wage. The setting of the wage rate is a complicated process that must respect the possibilities of a given company. Normally the productivity of an employee is somewhat higher than the wage while an employee must also be motivated to perform well.

This study is based on the statistical data concerning the average gross nominal monthly wage 


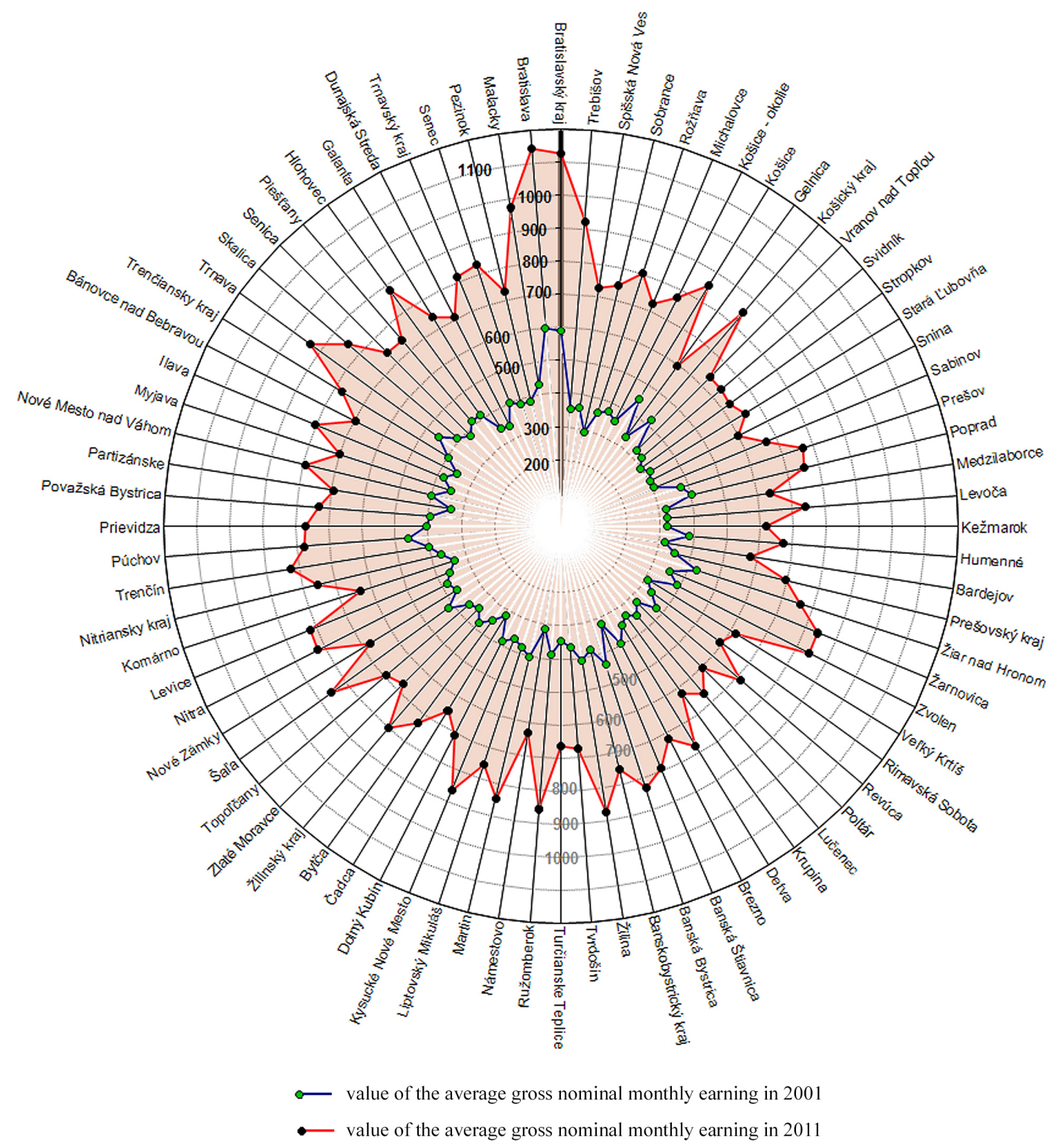

Fig. 2. Development of the average gross nominal monthly wage in Slovakia in 2001 and 2011. Source: Štatistický úrad Slovenskej republiky (2013a).

in 2001 and $2011^{2}$. Wages as the basic financial income are an important indicator for the identification of poor regions. However, unequal wages do not guarantee some employees that they do not fall below the poverty limit. Their wages can be so low that they do not cover the basic needs of household members. This phenomenon,

2 Monthly wage in 2001 was calculated by conversion rate $(30,126 \mathrm{SKK}$ - EUR). referred to as the working poor, is now given closer attention $^{3}$.

Mean nominal monthly wages in Slovakia in the decade in question increased more than twice (from $€ 424$ in 2001 to $€ 853$ in 2011). Fig. 2 illustrates the increase of wages at the national and regional levels.
Studies dealing with the working poor living abroad (Strengmann-Kuhn 2002; Shipler 2004; Sirovátka and Mareš 2006; Zuberi 2006; Fields 2012) prove it. 
The amount of the nominal and the real wage ${ }^{4}$ is controlled by inflation ${ }^{5}$, work productivity and unemployment ${ }^{6}$. The issue of increasing average nominal monthly wages is connected with household expenses - whether households can afford more goods and services or if their prices increased along with a rise in nominal wages and the amount of accessible goods and services remains equal. Household expenses did not grow in the same pace as the wages, albeit some increase was observed. This has improved the well-being of households and the rate of severe material deprivation dropped significantly (more than twice). To a lesser extent, the risk of poverty has fallen (ŠÚ SR 2017).

Wages and price of work in Slovakia, apart from the macro-economic effect (economic level, wage options) and conditions of employers, are also controlled by individual factors, such as efforts, education, capacities and skills of labour, etc. (Michálek 2007). The wage represents the basic income of a household. However, its low level does not have to mean the risk of poverty. In some regions, even the low wage covers the basic needs, while in others it does not. Low wage regions of Slovakia are the districts of the southern and eastern parts of the country. Low wage districts in 2001 are mostly similar to low wage districts in 2011. No deeper changes took place in terms of spatial differences in low wages.

\section{Poverty risk in terms of material deprivation}

Townsend introduced the measures of material deprivation (1979) and established an index of material deprivation by the combination of four variables (the unemployed, a household

4 The nominal wage is the amount of money received by a worker, no matter whether it is a task wage or a time wage. The real wage is the sum of goods and services a worker can pay from his/her nominal wage.

Inflation manifests itself by the growth in prices of products and services. From the macro-economic point of view, it is an increase in the overall price level, not only the growth in prices of individual products.

6 The relation between wages and unemployment is represented by the Phillips curve, where the growth in unemployment is accompanied by the reduction of wages. without a car, an overcrowded household, the ownership of a dwelling). OECD (2007) defines material deprivation as incapacity of households to afford goods and services typical of the society in a given time, regardless of their preferences. Other authors perceive material deprivation as exclusion from the acceptable way of life because of insufficient resources or the lack of basic needs perceived by the society (OECD 2008). Boarini et al. (2006) discern six main categories of deprivation items. The first category is the basic needs: food, clothes, and warmth. The second category is that of leisure time, particularly a week holiday away from home. The third category comprises an "object of long-term consumption": a TV set, a telephone and a car. Differences between countries in the ownership of long-term consumption objects are bigger than in the case of basic needs and leisure (OECD 2008). The category of a dwelling covers a WC inside the dwelling; dwellings needing repair and exposed to pollution. The dues and the problem of money shortage were classified into the category of a financial load. The last category is that of somebody else's assistance. Guio and Maquet (2006) classified deprivation items into three dimensions. Apart from the dimensions of the financial load and the ownership of long-term consumption objects, he included the one of a dwelling. The EU SILC (Štatistický úrad Slovenskej republiky 2012) analysing material deprivation works with nine deprivation items ${ }^{7}$ of the two dimensions: the dimension of a financial load and the ownership of long-term consumption objects. Material deprivation is an enforced shortage of at least four deprivation items. All the dimensions or categories mentioned contain mostly the same deprivation items. All the selected items capture a wide range of indispensable needs or those defined by society as necessary.

In this study, six deprivation items were selected in an effort to capture the widest possible spectre of needs. The first item is central heating the low percentage of which indicates a poor region where other types of heating prevail (are

\footnotetext{
Deprivation items: dues of rent, mortgage, energies, purchase instalments and other loans, a week holiday once a year, meat meal (or its vegetarian alternative) every other day, incapacity to face unexpected expenses, a telephone (including a cell phone), a colour TV set, a washing machine, a car, reasonable warmth.
} 
absent). The ownership of a car, a cell phone and a computer were chosen to represent long-term consumption objects. These items have become a common part of life, and their absence is typical of poor households ${ }^{8}$. The Internet connection is also a common item now owned by households. The last item is a water source outside a dwelling and dwellings lacking a water main. Such households are typical of the Roma settlements9. Nevertheless, it is also frequent in older houses in other settlements. Each deprivation item was evaluated separately, and subsequently, districts deprived of three or more items were identified.

In 2001, there were 14 districts deprived of three or more items (13 districts in 2011). Districts concurred (they were deprived in both years) in eight cases. Differences among these districts were observed only in the number of depriving items (Štatistický úrad Slovenskej republiky 2002, 2013b). Only two districts were deprived of the same number of items in both years. In 2011, five districts that were not deprived in 2001 joined the group. Worse status of the mentioned districts does not necessarily mean that there were any negative effects; it means only that their pace of "growth" was not as quick as that of other districts.

The character of material deprivation in terms of items should also be mentioned. Most districts in both years were deprived of two items, i.e. the ownership of a computer and the ownership of the Internet connection. The deprivation of these items was observed in twelve districts in both years. The second highest number of districts was observed in the ownership of a cell phone in 2001 (ten districts) and central heating in 2011 (ten districts). No water in a dwelling and water outside a dwelling in 2001 were found in nine districts, and in 2011, the ownership of a car was also found in nine districts. The lower number of deprived districts in 2001 was observed in the ownership of a car (seven districts) and in central heating (eight districts). The analysis suggests that no distinct change in the number of districts in individual items has taken place, but districts changed regarding the items.

\footnotetext{
Absence in some cases may mean a company's ownership of selected items; it does not have to be the case of poor households.

9 Segregated settlements of the Roma population.
}

\section{Poverty risk in terms of unemployment}

Unemployment in Slovakia assumed distinct economic, social and political dimensions, albeit it is also characterised by regional, socio-ecological, cultural, ethnic and generation specificities (Paukovič 2007). Unemployment is one of the principal and most important poverty indicators in Slovakia. It can lead to the financial crisis of individuals and households. Households struck by such crises face deficient income, material deprivation and most probably poverty.

Especially serious is long-term unemployment when households must face deprivation for a longer time when the probability of poverty risk increases. Mareš (1994) highlights the significance of information about long-term unemployment when the distribution of the unemployed by the duration of unemployment indicates its structure. It also facilitated the identification of problematic regions and social categories. Longterm unemployment does not afflict all population groups in the same way. Some of them are more threatened. Mareš (1994) describes seven population groups threatened by long-term unemployment: inflexible long-term unemployed labour (the more stable the job before its loss, the harder the search for a new job and the longer the time of unemployment), unqualified labour and persons with a low education level, persons with a series of cumulated social and personal disadvantages, ethnic minorities and immigrants, people from underdeveloped and rural regions, physically disabled, young people and fresh graduates. The author also asserts that the duration of unemployment is due to the inflexibility of the labour market (missing information about vacancies, the difference between demand and supply and the long-term inflexibility of the labour market - the reluctance of the jobless regarding the professional and spatial mobility).

Paukovič (2007) quotes factors that may determine the LTU rate and the dynamics of development in Slovakia: the instability of the government and public administration, wages lagging behind the European average, but also the increasing work productivity in recent years, overemployment in the state and public administrations as the consequence of low work productivity, deficient quality and work organisation, a meagre position of the tertiary sector, scarce 


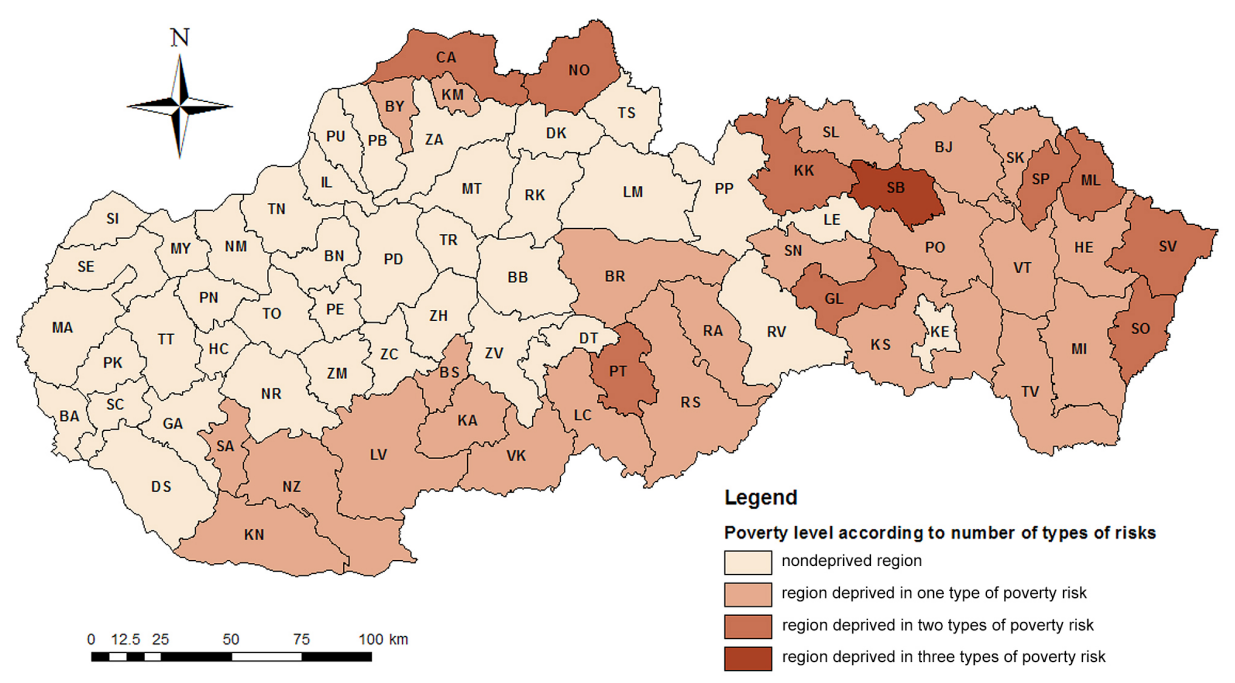

Fig. 3. Level of poverty in 2001.

Source: Štatistický úrad Slovenskej republiky (2002).

support to SME above all in tourism, a lack of resources for investments in constructions in economically underdeveloped regions of Slovakia, the education and qualification structure of the economically active population (which does not respond to the needs of the labour market), regional differences in unemployment low labour mobility, the inflexible and inadequate school system, lingering deformations in the social security system, a deficient active employment policy and the control of illegal work.

Long-term unemployment (over 24 months) has undergone an important change in the period concerned. While the proportion of the long-term unemployed (hereafter referred to as PLTU) ${ }^{10}$ in 2001 was $20.6 \%$, in 2011 it increased to as much as $30.6 \%$, a ten per cent increase (Ústredie práce, sociálnych vecí a rodiny 2013). LTU development was not "linear". It had a different trend until 2008. The distribution of long-term unemployment in 2001 was comparatively more regular with smaller interregional differences ${ }^{11}$. In 2001, the difference between the district with the top LTU and that with the lowest LTU was $21.9 \%$. In 2011, the difference was $49.3 \%$. The representation of individual districts with the top PLTU was also different. Districts with the top unemployment in both concerned years concurred

10 PLTU is computed as the proportion of the jobless unemployed more than 24 months to the total unemployed.

11 It was proven that the higher the values of the studied phenomena, the greater the interregional disparities. only in five cases. However, the LTU values in these districts were considerably higher in 2011. The districts of southern Slovakia prevailed in LTU in 2011. A higher proportion of the Roma ethnicity connected with the low level of education, scarce qualifications, negative working attitudes and reluctance to work characterises these districts. They also prevail in rural areas with a long farming tradition.

\section{Poverty regions and their development in terms of poverty risk}

The multidimensional analysis carried out has pointed, among other things, to the favourable trend, the decrease in the (absolute) number of poor districts in Slovakia. While in 2001 there were 33 poor districts, their number dropped to 24 (in total, regardless of the number of dimensions) in 2011. In 2001, there were 23 districts deprived of one type of risk, while in 2011 there were 11 (Figs 3 and 4).

Considering the two types of risk, in 2001 there were nine deprived districts, in 2011 there were seven districts. In terms of all three types of risks, in 2001 only one district was deprived. Ten years later, the number increased to six. This is the evidence of the deepening poverty. Apart from a quantitative change, qualitative changes also took place in the decade in question. In 2001, deprivation concerning LTU (13 districts) prevailed among districts deprived in terms of 


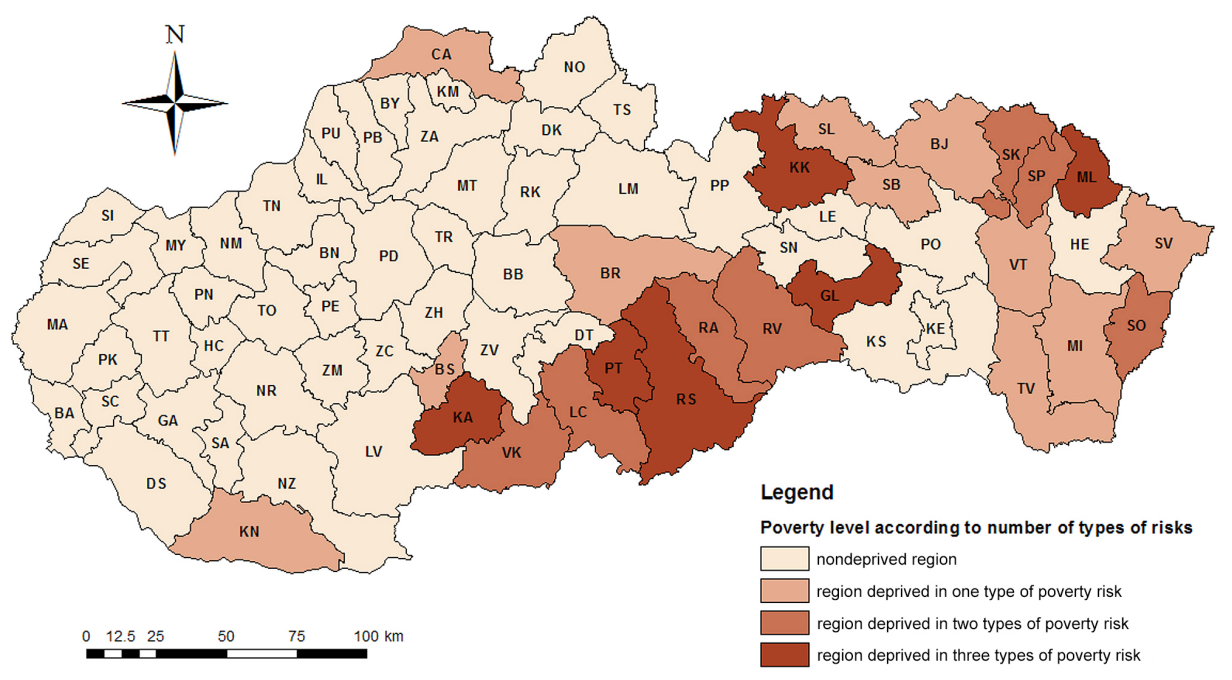

Fig. 4. Level of poverty in 2011.

Source: Štatistický úrad Slovenskej republiky (2013b).

only one type of risk, while ten years later it was in terms of wages (6 districts). In 2001, wage and material deprivation prevailed in these districts (8 districts). In 2011, poor regions in terms of material deprivation and LTU prevailed (4 districts). Qualitative changes were also important in districts in terms of individual dimensions or types of risks. Of 24 districts, which were deprived regarding one, two or three types of risk in 2011, 23 were also deprived in 2001. In five cases, there was no change in types of risks and the number of risks. In five districts, the number of types of risks did not change, but what changed was the character of the type of a risk. Poverty deepened in the remaining eleven districts. One type of a risk aggravated in eight cases, and two types of risks increased in three cases.

\section{Conclusion}

The results of this study suggest that Slovakia and its regions have been subject to considerable changes in the development of poverty risk in a comparatively short time. Between 2001 and 2011, quantity, but first of all, nature of poor regions, changed. In 2001, 33 poor regions were identified in the territory of Slovakia. Their number dropped to 24 in ten years. Spatial differences assessed in terms of quantity have not changed. In both years considered, poor regions (regardless of the poverty depth) prevailed in southern and eastern Slovakia. As far as quality is concerned, there were not only horizontal but also vertical changes. While at the beginning of the decade the deprivation of wages and material deprivation prevailed (8 of 9 districts), at the end of the decade, material deprivation and LTU prevailed (4 of 7 districts). The fact that while in 2001 there was only one district suffering from all three types of risks and in 2011 there were six districts in this category proves that poverty in Slovakia deepened over the studied decade. In the identified poverty districts, poverty is the worst, from the point of view of absolute values. This is evident in comparison with the absolute values of the most significant indicators of poverty in the databases ŠÚ SR, UPSVAR, Social Insurance Agency in Slovakia in 2011. Poverty not only deepened, but also the spatial differences changed. In 2001, there were poor regions in terms of two and three types of risks concentrated in eastern Slovakia. Ten years later, this concentration moved to southern districts of the country. Southern districts, identified as the most risky, should become priority in addressing problems connected with poverty, namely the proportion of long-term unemployment that increased by $10 \%$ in the period in question. Even though as far as time is concerned, the period 2001 - 2011 was fairly short, but it's importance is undeniable. In the aforementioned years many important events and changes took place (Slovakia joined the EU, the Eurozone, the financial crisis appeared) with an extensive impact on the economically vulnerable people living in these regions. The analysis and 
its results confirmed our hypothesis, that these but also other important phenomena and processes (e.g. the growth of inequalities) can have, even in a short time, an enormous impact on various, even spatial characteristics of poverty. They significantly change not only the level, dynamics and character of poverty, but also modify its regional differences and spatial concentration. This article introduces a pilot study, a contribution of which consists of two aspects. The first one is a theoretically-conceptual aspect, a method used and its application introduce generally valid theoretical framework designed to research spatial context of poverty. The second aspect consists of a particular analysis of progress and changes of poverty stricken population in the regions of Slovakia. The results identify regions with negative development and growing population living in poverty, to which we should turn our attention. The acquired information in the theoretically-conceptual domain or the specific empirical results introduce a framework, which could be applied even in other countries than Slovakia. This article is also the result of a reaction to current social challenges and demands associated with new approaches of social and regional policies, which are the indispensable source of information about the dynamics and changes of poverty levels in the regions.

\section{Acknowledgements}

The article was created with the support of scientific project no. 2/0101/15 financed by the VEGA grant agency.

\section{References}

Boarini R., Johansson A., Mira d'Ercole M., 2006. Alternative measures of well-being. OECD Social, Employment and Migration Working papers No. 33, OECD, Paris.

Fields G.S., 2012. Working hard, working poor. Oxford University Press, New York.

Guio A.C., Maquet I.E., 2006. Material deprivation and poor housing. Comparative EU statistics on income and living conditions: Issues and challenge. Luxembourg: Eurostat, Retrieved from http://www.stat.fi/eusilc/guio_maquet. pdf [accessed 29 June 2014].

Hrabcová D., 2000. Východiska a principy odměňování závislé práce v České republice (Background and principles of remuneration of dependent work in the Czech Republic). Masarykova univerzita, Brno.
Lipton M., 1997. Defining and measuring poverty: Conceptual issues. Human Development Report, New York.

Mareš P., 1994. Nezaměstnanost jako sociální problém (Unemployment as a social problem). Sociologické nakladatelství, Praha.

Michálek A., 2004. Meranie chudoby v regiónoch (okresoch) SR (Poverty measurement in the region (district) SR). Sociológia 36(1): 7-30.

Michálek A., 2007. Regionálne mzdové nerovnosti na Slovensku (Regional disparities in wages in Slovakia). Geografický časopis 59(2): 181-209.

Ministerstvo vnútra Slovenskej republiky 2004. Atlas rómskych komunit 2004 (Atlas of Roma communities 2004). Retrieved from http://www.minv.sk/?regiony_atlas [accessed 11 November 2013].

Nolan B., Whelan C.T., 1996. Measuring poverty using income and deprivation indicators. Alternative approaches. Journal of European Social Policy 6(3): 225-240.

The Organization for Economic Co-operation and Development 2007. Material deprivation. Retrieved from http:// stats.oecd.org/glossary/detail.asp?ID=7326 [accessed 29 August 2013].

The Organization for Economic Co-operation and Development 2008. Growing unequal? Income distribution and poverty in OECD countries. OECD. Retrieved from http:// www.oecd.org/els/soc/41527936.pdf [accessed 10 September 2013].

Paukovič V., 2007. Problém nezamestnanosti - Vybrané makrosociologické a mikrosociologické kontexty (The problem of unemployment - Sellected macrosociological and microsociological contexts). Sociálne a politické analýzy 1(1): 73-101.

Ravallion M., Sell B., 1996. When method matters: Monitoring poverty in Bangladesh. Economic Development and Cultural Change 44(4): 761-792.

Shipler D.K., 2004. The working poor: Invisible in America. Knopf Doubleday Publishing Group, New York.

Sirováka T., Mareš P., 2006. Chudoba, deprivace, sociální vyloučení: Nezaměstnaní a pracující chudí (Poverty, deprivation and social exlusion: The unemployed and the working poor). Sociologický časopis 42(4): 627-655.

Štatistický úrad Slovenskej republiky 2017. Miera závažnej materiálnej deprivácie. (Severe material deprivation rate). Retrieved from http://datacube.statistics.sk/\#!/view/ en/VBD_SK_WIN/kz1006rs/Severe \%20material\%20 deprivation $\% 20$ rate\%20\%5Bkz1006rs\%5D [accessed 18 October 2017].

Štatistický úrad Slovenskej republiky 2015. Základná štruktúra čistých peňažných výdavkov súkromných domácností. (Net monetary expenses of a household in Slovakia in 2001-2011). Retrieved from http://www.statistics. sk/pls/elisw/MetaInfo.explorer?obj=42 \&cmd=go\&s $=1002 \& \mathrm{sso}=2 \& \mathrm{so}=40$ [accessed 11 February 2015].

Štatistický úrad Slovenskej republiky 2013a. Priemerná nominálna mesačná mzda zamestnanca (EUR) podla: územie, SK NACE Rev. 2, pohlavie a rok (Average nominal monthly earning of employee (EUR) by territory, NACE, sex and period). Retrieved from http://px-web.statistics.sk/PXWebSlovak/ [accessed 22 September 2014].

Štatistický úrad Slovenskej republiky 2013b. Sč́tanie obyvatelov, domov a bytov 2011 (Population and Housing census 2011). Retrieved from http://census2011.statistics. sk/tabulky.html [accessed 5 September 2014].

Štatistický úrad Slovenskej republiky 2012. EU SILC 2011: Indikátory chudoby a sociálneho vylúčenia (EU SILC 2011: In- 
dicators of poverty and social exclusion). Retrieved from ftp://193.87.31.84/0206324/EU_SILC_2011_Indikatory_chudoby_a_socialneho_vylucenia.pdf [accessed 25 October 2015].

Štatistický úrad Slovenskej republiky 2002. Sčítanie obyvatelov, domov a bytov 2001. Základné údaje: Domy a byty. (Population and Housing census 2001). Bratislava: ŠU SR.

Strengmann-Kuhn W., 2002. Working poor in Europe: A partial basic income for workers? Retrieved from http:/ / www. basicincome.org/bien/pdf/2002Strengmann-Kuhn.pdf [accessed 3 June 2014].
Townsend P., 1979. Poverty in the United Kingdom. Allen Lane and Penguin Books, London.

Ústredie práce, sociálnych vecí a rodiny 2013. Nezamestnanost': štvrtročné štatistiky 2011(Unemployment: quarterly statistics). Retrieved from http://www.upsvar.sk/ statistiky/nezamestnanost-stvrtrocne-statistiky/2011. html?page_id=77441 [cit: 28-11-2013].

Wagle U., 2008. Multidimensional poverty measurement. Concepts and applications. Springer Science, New York.

Zuberi D., 2006. Social policy and the working poor in United States and Canada. Cornell University Press, New York. 